\title{
“ИЗМЕНЯЮЩАЯСЯ РОССИЯ: ПРОБЛЕМЫ БЕЗОПАСНОСТИ И ПОГРАНИЧНОЙ ПОЛИТИКИ”
}

\author{
В.Е. Хвощев
}

Хвощев Владимир Ефимович — кандидат философских наук, доцент, заведующий кафедрой политологии Южно-Уральского государственного университета (Челябинск).

27-28 июня 2002 г. в Челябинске усилиями Южно-Уральского государственного университета (ЮУрГУ) и Юго-Восточного регионального управления пограничной службы Российской Федерации (ЮВРУ ПС РФ) была проведена Вторая всероссийская научно-практическая конференция "Изменяющаяся Россия: проблемы безопасности и пограничной политики”, посвященная пограничной политике России в свете современной концепции государственной безопасности. На конференции рассматривались философские, политические, экономические, исторические аспекты безопасности личности, общества, государства и связанные с ними многочисленные проблемы современной российско-казахстанской границы. Стимулом для ее организации послужили результаты первого научного форума, состоявшегося годом раньше и привлекшего серьезный интерес к заявленной тематике.

Прежде всего необходимо сказать несколько слов об истоках партнерства вузовской науки южноуральского региона и пограничной службы. Наше сотрудничество возникло в тот исторический для России момент, когда мы, южноуральцы, из жителей географического центра Советского Союза превратились в население приграничной территории Российской Федерации и на южноуральской земле были дислоцированы погранвойска. Призванные защищать безопасность страны, пограничники ЮВРУ ПС РФ обратились за помощью к научному сообществу Южного Урала и стали налаживать контакты с вузами региона. Мы, университетские преподаватели, в свою очередь положительно откликнулись на такую инициативу, и теперь наши взаимоотношения уже имеют собственную историю.

В предлагаемой статье я хотел бы поделиться своими размышлениями по поводу обсуждавшейся на конференции в Челябинске темы и рассказать о той работе, которая была проделана моими коллегами по кафедре политологии ЮУрГУ в сотрудничестве со специалистами из Информационно-аналитического отдела ЮВРУ ПГ РФ.

В 2000 - 2001 гг. нашим коллективом была разработана программа социальной паспортизации территорий, примыкающих к российско-казахстанской границе, т.е. приграничных районов Волгоградской, Курганской, Новосибирской, Омской, Оренбургской, Самарской, Саратовской, Тюменской и Челябинской областей, а также Алтайского края. В ходе реализации программы обнаружилось, что наличие у всех перечисленных субъектов РФ своего “собственного” участка границы с Казахстаном создает ряд близких по сути проблем безопасности и пограничной политики. Другим результатом осуществления программы стало заключение о необходимости привлечения к решению этих проблем жителей названных территорий и действующих там институтов гражданского общества [Хвощев, Муллаянов 2001].

Социальная паспортизация российско-казахстанского приграничья позволила организовать два широкомасштабных социологических опроса. Первый из них был проведен осенью 2000 г. в десяти приграничных субъектах юго-восточного региона России по анкете “Человек и граница” (выборка - 8240 чел.). Второй состоялся осенью 2001 г., тоже в десяти субъектах, и для него мы избрали другую тему: “Безопасность и граница” (выборка - 9184 чел.). Цель обоих опросов была единой — создание научного банка данных для систематического проведения мониторингов по выявлению особенностей индивидуального и общественного сознания и поведения различных слоев приграничного населения, в первую очередь молодежи, и влияния на их формирование “феномена границы”. 
выдвинутую гипотезу о том, что характерными чертами нового поколения россиян являются пониженная чувствительность к опасностям, которые несет в себе пограничный фактор, и неадекватное, иногда доходящее до легкомыслия, отношение к границам. Но если пренебрежение людей к государственной границе навеяно, скорее всего, их устремленностью к “открытому обществу” (граница у многих ассоциируется с досадной помехой свободе), то чем объясняется игнорирование ими проблемы опасности и безопасности? По всей видимости, дело в том, что понятие безопасности общества и государства — одно из фундаментальных для современного мира — приобрело в сознании россиян (по крайней мере, южноуральцев) расплывчатый характер и нуждается в серьезной научной проработке и корректировке. Безопасность пока что остается пропагандистским штампом с широким и во многом неопределенным смыслом. Наше заключение носит предварительный характер, но в его пользу, помимо всего прочего, говорит то обстоятельство, что интерес к предмету границы обычно усиливается или затухает в зависимости от политической конъюнктуры. С середины 1990-х годов в нашей стране наблюдалось заметное снижение внимания к проблеме государственных границ со стороны высших политических руководителей страны [Хвощев 2002]. Поворотными в этом отношении стали события 11 сентября 2001 г. в Нью-Йорке, сразу же актуализировавшие вопросы безопасности [Муллаянов, Хвощев 2002: 75-79]. На их фоне резко возросла потребность в уточнении представлений россиян о безопасности страны.

Проведенные в Южно-Уральском регионе социологические опросы показали, что наиболее распространенными сегодня являются следующие взгляды.

Первая и наиболее многочисленная категория жителей нашего приграничья отождествляет безопасность с военной мощью государства. Логика их рассуждений предельно проста - опасности подстерегают слабого, поэтому для укрепления безопасности следует вооружаться. Однако сила, как правило, пренебрегает согласием, а значит, безопасность, построенная на ней, не может быть всеобщей. Преодолеть это противоречие, как показывает практика международных отношений, нельзя и с помощью налаживания “баланса сил”, поскольку равновесие в мировой политике ненадежно и скоротечно, а неуязвимость даже мощной в военном отношении державы вызывает много сомнений.

Позиция другой группы населения региона основана на преувеличении взаимосвязи между безопасностью и потребностями государств. Любое пренебрежение последними приравнивается носителями таких взглядов к покушению на безопасность. Подобный подход открывает широкие возможности для манипуляции интересами личности, общества и государства под вывеской безопасности.

Третья категория южноуральцев (их позиция представляется нам наиболее рациональной) прочно ассоциирует понятие безопасности с границами. Наличие границ — реальность сегодняшнего мира, и потому безопасность человека неизбежно связана (осознается это или нет) с территорией и ее рубежами. Человек - одновременно и разрушитель границ, и их созидатель. Для него граница - это препятствие на пути к свободе, с одной стороны, и тот рубеж обороны от возможного внешнего вторжения, который он строит и укрепляет, - с другой. Такое двойственное, дихотомичное отношение к границам позволяет установить, пусть временный и зыбкий, порядок взаимодействия сторон, внести предсказуемость в их отношения.

На фоне глобальных перемен последнего времени может показаться, что границы в жизни современного общества теряют свое значение, что приближается время “гуманистических” решений вопросов безопасности. Однако вся мировая практика убеждает в том, что утопия под названием “мир без границ” может привести лишь к войнам без правил и фронтов. Обустраивая и оберегая границы, человек заботится о безопасности, а думая о безопасности, прежде всего имеет в виду конкретные пределы, рубежи своей земли. Не случайно в современных языках все чаще используются такие парные понятия, понятия-“спутники”, как государственные границы и государственная безопасность, экономические границы и экономическая безопасность, национальные границы и национальная безопасность, информационные границы и информационная безопасность, региональные границы и региональная безопасность, экологические границы и экологическая безопасность.

Особого разговора заслуживает крайне слабое отражение рассматриваемой тематики в вузовских программах и учебных курсах. Так, в учебниках по политологии, предметом которой должны были бы быть многие процессы, связанные с безопасностью государств и их границами, редко встречается даже упоминание о соответствующих явлениях и понятиях. Нет их ни в государственных образовательных стандартах, ни в энциклопедиях по политологии. 
С целью концентрации научного потенциала в решении этой более чем актуальной проблемы на базе ЮУрГУ создан Юго-Восточный институт геополитики, а по рекомендации Государственной Думы разработана и внедряется система геополитического образования студентов. Уже в течение нескольких лет в нашем университете осуществляется дистанционное обучение студентов по специальности “политология и геополитика” с использованием программ Стэнфордского университета и с привлечением профессуры этого весьма известного учебного заведения. Дисциплины, читаемые американскими специалистами, непосредственно затрагивают вопросы международной и экологической безопасности, а традиционная для политической науки США тщательная учебно-методическая проработка предмета не оставляет сомнений в том, что проблемы безопасности и границ можно и нужно изучать в современном российском вузе.

В заключение отмечу, что в издательстве ЮУрГУ готовится к печати коллективный труд участников Второй всероссийской научно-практической конференции под названием “Мир без границ — война без фронтов и правил”, а организационный комитет приступил к подготовке третьего форума, проведение которого планируется на 2003 г.

Муллаянов Р.Ш., Хвощев В.Е. 2002. Активизация международного терроризма и новые проблемы российско-казахстанской границы. - Вестник Южно-Уральского государственного университета. Серия 1: Социально-гуманитарные науки. Челябинск.

Хвощев В.Е. (ред.). 2002. Границы безопасности и безопасность границ. Челябинск.

Хвощев В.Е., Муллаянов Р.Ш. 2001. Пограничная политика и безопасность. Опыт регионального анализа. Челябинск.

Хвощев В.Е., Муллаянов Р.Ш. (ред.) 2002. Безопасность и граница. Российско-казахстанское приграничье. Одномерные статистические распределения. Челябинск.

Работа выполнена при финансовой поддержке Российского гуманитарного научного фонда (проект 0203=00151 г/Т), Челябинской областной администрации, а также при участии Челябинского отделения Российской ассоциации политической науки. 